ЛИСЬКО

Тетяна Давидівна tetiana.lysko@npp.nau.edu.ua

к.ю.н., дочент кафедри,

Наиіональний авіаичійний університет
УДК 343.46

КРИМІНАЛЬНО-ПРАВОВИЙ ЗАХИСТ ТРУДОВИХ ПРАВ, СВОБОД ТА СОЦІАЛЬНИХ ІНТЕРЕСІВ: ДОСВІД ЗАРУБІЖНИХ КРАЇН

\title{
PROTECTION OF THE LABOR RIGHTS, FREEDOMS AND SOCIAL INTERESTS IN THE CRIMINAL LAW: EXPERIENCE OF FOREIGN COUNTRIES
}

\author{
DOI: https://doi.org/10.37634/efp.2020.5(2).6
}

\section{LYSKO Tetiana Davydivna - PhD in Law, Associate Professor of department, National Aviation University}

У статті з використанням порівняльно-правового методу здійснено аналіз окремих положень кримінального законодавства зарубіжних краӥн, щьо забезпечують захист трудових прав, свобод та соціальних інтересів. Автором констатовано, щңо охорона трудових прав в сучасному кримінальному законодавстві зарубіжсни країн нерідко носить досить фрагментарний, несистемний характер. Вказано вади вітчизняного законодавства та підкреслено основні позитивні зрушення в цій иарині $з$ прийняттям КК України 2001 р. Зроблено висновок, щзо перелік злочинів проти трудових прав, які передбачені в сучасних кримінальних законодавствах, достатньо потужний, характеризується специффічними ознаками та в окремих випадках може слугувати орієнтиром для вдосконалення украӥнського кримінального законодавства.

$$
* * *
$$

В статье с использованием сравнительно-правового метода произведено анализ отдельных положений уголовного законодательства зарубежных стран, обеспечивающих защиту трудовых прав, свобод и социальных интересов. Автор констатирует, что охрана трудовых прав в современном уголовном законодательстве зарубежсных стран нередко носит достаточно фрагментарный, несистемный характер. Указано недостатки отечественного законодательства и подчеркнуто основные позитивные сдвиги в этой области после принятия УК Украины 2001 г. Сделан вывод, что перечень преступлений против трудовых прав в современных уголовных законодательствах, достаточно мощный, характеризуется специфическими признаками и в отдельных случаях может служить ориентиром для усовершенствования украинского уголовного законодательства.

$$
* * *
$$

The analysis of certain points of the criminal legislation of the foreign countries, which provide protection of labour rights, freedoms and social interests, is made in the paper with the help of comparative legal analysis. Despite the quite wide legal regulation of labour relations in all countries in the world, the special criminal law protection of labour rights has remained a feature of "eastern" countries of the continental family of law mainly, the so-called post-socialist family of law.

The analysis of criminal legislation of foreign countries regarding criminalization of the violation of labour rights of a person is conducted in the paper. Comparative-legal analysis allows defining general approaches to formation of labour rights of employees, including in the sphere of contractual relationship. The most similar and corresponding to the national criminal legislature are the Criminal codes of Spain an Polish Republic, which establish criminal liability for violation of not only labour legislation in force, but also conditions of individual labour acts (agreements, contracts etc.).

It is stated in the text that the protection of labour rights in the modern legislation of foreign countries often has fragmentary, unsystematic nature. The violation of labour safety rules is most often regulated in the criminal legislation of foreign countries. Other types of violation of the labour legislation are regulated with arbitration under administrative or civil legislation.

The drawbacks of the fatherland's legislation are mentioned and the main positive improvements in this sphere after adoption of the Criminal Code of Ukraine in 2001 are emphasized. It was made the conclusion that the list of crimes against labour rights, which are provided by modern criminal legislations, is strong enough and has specific features. The list mentioned above could be the target for improving Ukrainian criminal legislation in certain cases. Therewith it is important to remember that formation of the legislation in the sphere of the protection of labour rights, freedoms and social interests directly depends on the development of the regulatory legislation. It is the clarity and certainty of blanket norms that will become the fundamental basis for the formation of effective criminal law protection of labour rights, freedoms and interests.

Ключові слова: захист трудових прав, охорона прачі, порівняльно-правовий аналіз

Ключевые слова: защита трудовых прав, охрана труда, сравнительно-правовой анализ

Keywords: protection of the labour rights, labour protection, comparative legal analysis

\section{ВСТУП}

Трудові права займають провідне місце серед основних соціально-економічних прав людини і громадянина. Як зазначають науковці, у кримінальному законодавстві нашої держави було запроваджено цілісну систему кримінально-правового захисту трудових прав людини (ст.ст. 170-175 розд. V «Злочини проти виборчих, трудових та інших особистих прав і свобод людини і громадянина») [1, с. 58]. Чинний КК Укра- їни увібрав норми, які захищають права працівників, передбачені не лише трудовим законодавством, а й договірними відносинами між роботодавцем та працівником. Вперше у кримінальному законодавстві з'являється ст. 173 КК України, яка передбачає відповідальність за грубе порушення угоди про працю, тобто порушення прав, передбачених індивідуальними умовами угоди між роботодавцем і працівником. Залишаються і традиційні кримінально-правові нор- 
ми, пов'язані із захистом прав професійних спілок (ст. 170 КК України), прав працівників, передбачених законодавством про працю (ст. 172 КК України), трудових прав журналістів (ст. 171 КК України) й окремих особливих прав працівників, як право на страйк та своєчасне отримання заробітної плати (ст. ст. 174, 175 КК України).

\section{МЕТОДИ ДОСЛІДЖЕННЯ}

Методологічною та інформаційною основою роботи є наукові публікації, роботи та дослідження вітчизняних науковців. Під час проведення дослідження було застосовано компаративіський метод (порівняльно-правовий), який надав змогу здійснити комплексний аналіз кримінального законодавства окремих зарубіжних країн у частині захисту трудових прав, свобод та соціальних інтересів. Крім того, застосовано методи системного аналізу та узагальнення.

\section{ПОСТАНОВКА ЗАВДАННЯ}

Як зазначає М.П. Куцевич, несистемність правових норм, дублювання і навіть колізії у трудовому та кримінальному законодавстві у сукупності зумовлюють необхідність формування належної концепції побудови системи захисту трудових прав працівника [2, с. 7]. Для вирішення вказаного питання вважаємо корисним звернутися до досвіду окремих зарубіжних країн.

\section{РЕЗУЛЬТАТИ}

Не зважаючи на достатньо широку правову регламентацію трудових правовідносин у всіх країнах світу, спеціальна кримінально-правова охорона трудових прав залишилась рисою переважно «східних» країн континентальної сім’ї права, так званої постсоціалістичної сім’ї права.

Спеціальні склади злочинів проти трудових прав або трудових відносин містяться в КК Грузії, КК Вірменії, КК Білорусі, КК Молдови, КК Таджикистану, КК Узбекистану, КК РФ, країн Балтії, Канади, Албанії, Андори, Болгарії, Болівії, Бразилії. Венесуели, В'єтнаму, Іспанії, КНДР, Куби, Монголії, Парагваю, Польщі, Румунії, Сальвадору [3, с. 164].

Склади вказаних злочинів носять переважно банкетний характер. Як наголошує С.Я. Лихова, правові відносини, врегульовані нормами трудового права залишаються поза межами механізму кримінальноправового регулювання, який, діючи в загально-охоронному режимі, «включається» лише тоді, коли вказані правовідносини порушуються, тобто вчиняється злочин (хоча під правопорушенням у широкому плані мають на увазі не тільки злочини) [4, с. 79].

Тому у багатьох країнах законодавець надає перевагу локальному законодавчому регулюванню таких правовідносин. Так, у Франції відповідальність за порушення законодавства про охорону та гігієну праці містяться безпосередньо в Трудовому кодексі.

КК ФРН містить норму «Приховування і розтрата заробітної плати» (\$266а), але кримінально-правий зміст іiї полягає в попередженні ухилення від виплати внесків по соціальному страхуванню, а також захист працівника від деяких спеціальних випадків зловживання його довірою. По суті вказана норма співвідноситься зі ст.ст. 212, 212-1 КК України у частині ухи- лення від сплати зборів та єдиного внеску на загальнообов'язкове державне соціальне страхування та страхових внесків на загальнообов'язкове державне пенсійне страхування, хоча іiі техніко-юридична будова суттєво відрізняється. Охоронюване благо за §266а КК ФРН - інтереси забезпечення надходження засобів для соціального страхування та інтереси найманих працівників в частині довірчого управління частиною їх доходів. У літературі точаться дискусії про те, що це за внески, які строки платежів, але власне діяння є у формі бездіяльності: особа а) не сплачує внески; б) для неї це можливо і доступно [5, с. 476].

Охорона трудових прав у сучасному кримінальному законодавстві зарубіжних країн нерідко носить досить фрагментарний, несистемний характер.

Так, у КК Молдови, Латвії, Монголії посяганням на трудові права присвячена всього одна стаття. Наприклад, ст. 183 КК Молдови встановлює відповідальність лише за порушення правил охорони праці посадовою особою, управляючим комерційною, громадською або іншою недержавною організацією, у випадку, коли такі дії «призвели до нещасного випадку серед людей або до інших тяжких наслідків». Кваліфікований склад злочину має місце у випадку, коли порушення правил техніки безпеки, виробничої гігієни або інших правил охорони праці призвели до смерті потерпілого через необережність.

У деяких країнах законодавець виокремлює злочини проти трудових прав громадян в спеціальні глави чи розділи (Федерація Боснії і Герцеговини, Бразилія, Венесуела, Іспанія, КНДР, Куба, Македонія, Польща, Румунія, Сальвадор, Сербія, Словенія, Чорногорія). Наразі на українському науковому полі існують концепції стосовно виокремлення та систематизації статей, що посягають на трудові права, свободи. Так, М.П. Куцевич пропонує виокремити вказані суспільно небезпечні діяння в окремий розділ «Злочини проти трудових прав» [2, с. 434]. 3 погляду системного підходу до встановлення кримінальної відповідальності за порушення трудових прав і свобод, така думка є слушною.

Доволі широко виписані норми, що встановлюють кримінальну відповідальність за порушення трудових прав, у КК Іспанії. Розд. 15 «Про злочини проти прав трудящих» містить 8 статей (ст.ст. 311-318 КК). Так, за ст. 311 КК Іспанії карається тюремним ув'язненням на строк від шести місяців до трьох років i штрафом на суму до 12 місячних заробітних плат той, хто обманом або зловживаючи становищем необхідності піддає найманих працівників таким умовам роботи або соціальної безпеки, які заподіюють шкоду, скасовують або обмежують їх права, визнані законами, колективними договорами чи індивідуальними контрактами. Якщо це діяння вчиняється із застосуванням насильства або залякування, покарання підвищується на один ступінь. Ст. 312 КК встановлює відповідальність за незаконну торгівлю робочою силою, а у ст. 313 йдеться про покарання за нелегальну міграцію працівників в Іспанію або сприяння цьому будь-яким способом. Відповідальність за дискримінацію на державній чи приватній роботі з мотивів ідеології, релігії, переконання, етнічної, расової чи національної приналежності працівника, його статі, сексу- 
альної орієнтації, сімейного становища, хвороби або інвалідності тощо, встановлюється ст. 314 КК у вигляді тюремного ув'язнення від 6 місяців до 2 років або штрафом на суму від 6 до 12 місячних зарплат. Відповідальність за перешкоджання або обмеження свободи діяльності профспілок або права на страйк шляхом обману чи зловживаючи ситуацією крайньої необхідності встановлюється ст. 315 КК. Той, хто порушує норми попередження виробничого ризику i, маючи законний обов'язок, не надає засоби, необхідні для того, щоб працівники здійснювали свою діяльність 3 дотриманням адекватних заходів безпеки і гігієни, у формі, яка ставить в серйозну небезпеку їх життя, здоров'я чи фізичну цілісність, карається тюремним ув'язненням на строк від 6 місяців до 3 років і штрафом на суму від 6 до 12 місячних зарплат (ст. 316 КК). Ст. 317 КК містить привілейований склад злочину - якщо вказані дії були вчинені за грубої необережності, покарання призначається на один ступінь нижче. Ст. 319 КК містить застереження стосовно відповідальності юридичних осіб за перераховані вище дії: «...вказана міра покарання призначається керівникам або співробітникам, що відповідають за ці діяння, і тим особам, котрі свідомо і, маючи можливість виправити становище, не вживають заходів до цього».

За такої розширеної регламентації суспільно небезпечних діянь, що посягають на трудові права громадян, у КК Іспанії жодного слова про відповідальність за невиплату заробітної плати, стипендії, пенсії чи інших установлених законом виплат.

Натомість чинне кримінальне законодавство України містить ст. 175 КК, що передбачає відповідальність за безпідставну невиплату заробітної плати, стипендії, пенсії чи іншої установленої законом виплати громадянам більш як за один місяць, вчинена умисно керівником підприємства, установи або організації незалежно від форми власності чи громадянином - суб'єктом підприємницької діяльності. Як слушно зазначав М.І.Хавронюк, ст. 175 КК України є прикладом надмірної криміналізації, оскільки за таке саме діяння встановлена адміністративна, дисциплінарна, матеріальна і цивільно-правова відповідальність. Крім того, ч. 2 ст. 175 КК України створює небажану конкуренцію зі ст. 210 КК України (нецільове використання бюджетних коштів службовою особою) [6, с. 178$]$.

Перелік злочинів проти трудових прав, які передбачені у сучасних кримінальних законодавствах, достатньо потужний. Зокрема, у кримінальному законодавстві зарубіжних країн містяться такі склади злочинів:

- посягання на свободу праці (Болівія, Бразилія, Грузія, КНР, Колумбія, Франція, Хорватія);

- порушення правил охорони праці (країни СНД і Балтії, Болгарія, В'єтнам, Іспанія, КНР, Куба, Парагвай, Румунія);

- перешкоджання діяльності профспілок або свободі профоб’єднань (Бразилія, Вірменія, Іспанія, Литва, Україна);

- неодноразова затримка особою, що виконує управлінські функції, виплати заробітної плати (Казахстан), затримка виплати заробітної плати (Таджи- кистан);

- невиплата заробітної плати, пенсії, стипендії, грошової допомоги та інших виплат (РФ, Україна);

- порушення права на страйк (Грузія, Іспанія, Македонія, Сальвадор, Хорватія, Чорногорія);

- примушування до участі у страйку або відмови від участі у страйку (Албанія, Білорусь, Казахстан, Україна);

- завідомо незаконне звільнення працівника (Білорусь, Грузія, Казахстан, Киргизстан, Україна, Таджикистан);

- необгрунтована відмова у прийомі на роботу або необгрунтоване звільнення жінки через вагітність або необгрунтована відмова у прийомі на роботу або необгрунтоване звільнення 3 роботи жінки, що має дітей у віці до трьох років (Азербайджан, Вірменія, Казахстан, Киргизстан, РФ, Україна, Таджикистан);

- інше порушення законодавство про працю, яке заподіяло суттєву шкоду правам і законним інтересам громадян (Білорусь, Казахстан);

- інше умисне порушення законодавства про працю (Киргизстан, Таджикистан).

\section{ВИСНОВКИ}

Таким чином, як показує порівняльний аналіз, єдиний підхід до кримінально-правової охорони трудових прав відсутній. Найбільш часто піддається регламентації у кримінальному законодавстві зарубіжних країн порушення правил безпеки праці. Інші види порушень трудового законодавства регулюються арбітражем, адміністративним або ж цивільним законодавством.

Водночас слід пам'ятати, що становлення законодавства у сфері захисту трудових прав, свобод та соціальних інтересів прямо залежать від розвитку регулятивного законодавства. Саме чіткість та визначеність бланкетних норм стане фундаментальною основою для формування дієвого кримінально-правового захисту трудових прав, свобод та інтересів.

\section{Список використаних джерел}

1. Танаджі В.Г. Кримінально-правовий захист прав працівників у договірних відносинах з роботодавием $(\mathrm{cm}$. 173 КК Украӥни): дис. ... канд. юрид. наук: 12.00.08 / Харківський національний університет внутрішніх справ. Харків, 2019. 214 c.

2. Кучевич М.П. Проблеми захисту трудових прав працівника засобами кримінального права: дис. ... д-ра юрид. наук.: 12.00.08 / Національний університет «Одеська юридична академія». Одеса, 2018. 467 c.

3. Сравнительное уголовное право. Особенная часть: монография / под ред. д.ю.н., проф. С.П.Щербы. М.: Издательство «Юрлитинформ», 2010. 543 с.

4. Лихова С.Я. Злочини у сфері реалізачії громадянських, політичних та сочіальних прав $і$ свобод людини $i$ громадянина (розділ $V$ Особливої частини KK Украӥни): монографія. К.: Київський університет, 2006. 573 $c$.

5. Жалинский А.Э. Современное немеикое уголовное право. М.: ТК Велби, Изд-во Проспект, 2006. 560 с.

6. Хавронюк M.I. Довідник з особливої частини Кримінального кодексу України. К.: Істина, 2004. 504.

\section{References}

1. Tanadzhi V.H. Criminal protection of employees' rights in contractual relations with the employer (art. 173 of the Criminal Code of Ukraine): dys. ... cand. law sciences: 
12.00.08 / Kharkiv National University of Internal Affairs. Kharkiv, 2019. 214 p. (in Ukrainian).

2. Kutsevych M.P. Problems of protection of labour rights of the employee by means of criminal law: diss. ... doctor law sciences: 12.00.08 / National University "Odessa Law Academy". Odesa, 2018. 467 p. (in Ukrainian).

3. Comparative criminal law. Special part: monograph / ed. S.P. Shcherba. Moscow: Yurlitinform, 2010. 543 p. (in Russian).

4. Lykhova S.Ya. Crimes in the sphere of realization of civil, political and social rights and freedoms of man and citizen (Chapter $V$ of the Special Part of the Criminal Code of Ukraine): monograph. Kyiv: Kyivs university, 2006. 573 p. (in Ukrainian).

5. Zhalinskiy A.E. Modern German criminal law. Moscow: TK Velbi. Izd-vo Prospekt. 2006. 560 p. (in Russian).

6. Khavroniuk M.I. Reference book of a Special Part of the Criminal Code of Ukraine. Kyiv: Istyna, 2004. 504 p. (in Ukrainian). 